Cumhuriyet International Journal of Education-CIJE

e-ISSN: $2147-1606$

Vol 5 (1), 2016, $10-28$

\title{
Pre-Service Classroom Teachers' Critical Thinking Tendencies and Attitudes towards Reading Habit
}

\author{
İclal GÖKKUŞ, Burak DELİCAN
}

\author{
SUMMARY
}

\section{INTRODUCTION}

It is clear that pre-service teachers should improve their reading habit and skill of critical thinking in education process. The aim of this study is to put forward pre-service classroom teachers about critical thinking levels and attitudes towards reading habits and determine whether there is a relation between these two.

\section{METHOD}

This study is a descriptive correlational study. 201 pre-service classroom teachers who study at third and fourth class of Cumhuriyet University Education Faculty Elementary Education Department in 2012-2013 academic year compose study group of research. In order to collect data about pre-service classroom teachers about critical thinking level and attitude of reading habit, two data collection tools were used namely "California Critical Thinking Disposition Inventory (CCTDI)" and Attitude Scale on Reading Habit (ASRH)". Internal consistency coefficient of both scales was "0,88". According to research data, reliability coefficient of the scales were respectively " 0,83 and 0,93 ".

In the statistical analysis of data of the study, arithmetic average, standard deviation, frequency and percentage calculations, independent samples t-test, Pearson correlation analysis were used.

\section{RESULTS}

As a result of analysis, it was determined that critical thinking tendency of pre-service classroom teachers is at medium level and when sub-dimensions are analyzed; dimensions of "being open-minded (Zayif, 2008), analytic (Zayif, 2008), systematic, self-confident, curious" is at medium thinking level for pre-service classroom teachers; and at low critical thinking level in "searching for the right" (Zayif, 2008) dimension. It was observed that critical thinking tendency is not significantly different according to gender variable; yet there was a significant difference on behalf of students reading at fourth class in the sense of classroom variable.

It was observed that attitudes towards reading habit was positive and at the level of "I totally agree". When scores at sub-dimension are considered, it was determined that attitude of students towards reading habit is at the level of "I agree" in dimensions of desire, loving and requirement while it was at the level of "I totally agree" in dimensions of benefit, effect and habit. It was determined that attitudes towards reading differ significantly on behalf of female students according to gender variable and on behalf of fourth class students according to classroom variable.

It was found that there is medium level, positive and significant relation between critical thinking tendency and attitude towards reading habit of pre-service teachers

\section{DISCUSSION}

Studies generally state that in our country critical thinking tendency of pre-service teachers is not at sufficient level. Critical thinking process and skills cannot be adopted as a subject only in courses. These characteristics of students should be supported with activities inside and outside the class together with their teachers and friends. Although university students have a positive or negative thought or attitude towards a subject, they should adopt 
behavior of obtained data in critical sense in university environment (Ikuenobe,2001; Doğanay,Taş \& Enden,2007,p.534).

According to research findings, it was observed that scores belonging to "loving, desire and requirement" dimensions of pre-service teachers' attitude towards reading habit is lower compared to other dimensions. Decrease of reading love especially among children and young people would cause problems in the future of society, and in the cultural, scientific, artistic world (Yalçın,2004). Since reading habit first of all depends on book love and interest, every step taken on this issue should be paid attention. Reading habit can develop when reading becomes a personal pleasure and hobby, when it is done heartily (Gönen,Celebi \& Işıtan,2004). Density of students during their university educations causes them not spend enough time to read book and generally push reading into the background. Therefore, attitude of students about regarding reading as necessary might be found less positive compared to other dimensions (Yılmaz Doğan,2010,p.81).

\section{SUGGESTION}

In order to raise pre-service teachers who think, interrogate, read; both thinking process of pre-service teachers and intellectual development of them should be supported. 